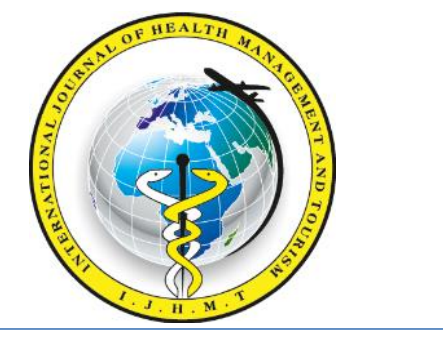

International Journal Of Health Management And Tourism

\title{
THE FUNDING STRUCTURE OF TURKISH TOURISM SECTOR AND A MODEL PROPOSAL FOR TOURISM REVENUE
}

\author{
Neslihan TURGUTTOPBAS \\ Associate Prof, Atılım Univesity, School of Business, Ankara, Turkey \\ E mail: neslihan.turguttopbas@atilim.edu.tr
}

Received: 2019-02-18

Accepted: 2019-04-29

\begin{abstract}
For decades Turkey has strived for increasing tourism revenues with the ultimate aim to reduce the current account deficit. Turkish governments have offered several incentives such as reduced utility prices, funding alternatives for tourism investments and reduced tax rates, while pursuing policies aimed at eliminating any bureaucratic barriers that may hinder growth in the tourism sector. An official document which incorporates an ambitious and extremely detailed plan to achieve 50 million tourist arrivals and revenues of USD 50 billion by 2023 is on the agenda. This paper is prepared for contributing to the literature on tourism economics based on Turkey which is rare. The aim of this study is twofold; firstly the debut analysis of the funding structure of Turkish tourism sector is realized by using the aggregate balance sheet of 555 tourism companies. The data represents the general structure of the tourism sector as capital intensive and the major source of funding is mainly borrowing from the financial institutions. Then, a model is proposed by using the linear regression by which the effects of the variables of public incentive disbursements, terrorism index, real effective foreign exchange rate, share of loans to tourism sector in total loans provided by financial system, average expenditure incurred by tourist and the tourism receipt level of major and geographically more substitute competitor of Greece on Tourism revenue level is examined.
\end{abstract}

Keywords: tourism revenue; funding source; tourism

Jel codes: L83, Z32, Z33 


\section{Introduction}

Turkey recorded a current account deficit of 5.50 percent of Gross Domestic Product in 2017 reaching a level of $\$ 47.3$ billion, with a rate of increase $42.9 \%$ as compared to the previous year's figure of $\$ 33.1$ billion. In fact, current account deficit in Turkey has been quite volatile and fluctuating at high levels in recent years and the governments have been in search to overcome this problem by any means of foreign exchange generating activities, the most important which is tourism.

The following Table 1 summarizes the developments in Turkish tourism indicators in the period 2011-2017. 2015 was the year when the rather consistent increasing trend in the tourism receipts reversed caused by many factors, the most important of which is accepted as the political tensions caused by foreign policy. Besides, the number of visitors did not change, $8.7 \%$ decrease in the average expenditure caused a comparable rate of decrease above $8 \%$ in the tourism receipts in 2015 . The situation was worsened in 2016; when both number of visitors and the average expenditure decreased by $24.6 \%$ and $6.75 \%$ respectively which caused a surge in tourism receipts of $29.7 \%$ and diminishing it to a level realized a decade ago. 2017 was a year of rebound; despite the decrease in the average expenditure, mainly stemming from the devaluation, the tourism receipts were increased by $18.9 \%$ to a level of 26.3 billion $\$$.

Table 1. Tourism Indicators of Turkey in the Period 2011-2017

\begin{tabular}{|c|c|c|c|c|c|c|}
\hline & $\begin{array}{c}\text { Tourism } \\
\text { Receipts } \\
\mathbf{( 1 0 0 0 \$ )}\end{array}$ & Change & $\begin{array}{c}\text { Number } \\
\text { of Visitors }\end{array}$ & $\begin{array}{c}\text { Average } \\
\text { Expenditure } \\
\mathbf{( \$ )}\end{array}$ & Change \\
\hline 2011 & 28.115 .692 & & 36.151 .328 & & 778 & \\
\hline 2012 & 29.007 .003 & $3,17 \%$ & 36.463 .921 & $0,86 \%$ & 795 & $2,19 \%$ \\
\hline 2013 & 32.310 .424 & $11,39 \%$ & 39.226 .226 & $7,58 \%$ & 824 & $3,65 \%$ \\
\hline 2014 & 34.305 .904 & $6,18 \%$ & 41.415 .070 & $5,58 \%$ & 828 & $0,49 \%$ \\
\hline 2015 & 31.464 .777 & $-8,28 \%$ & 41.617 .530 & $0,49 \%$ & 756 & $-8,70 \%$ \\
\hline 2016 & 22.107 .440 & $-29,74 \%$ & 31.365 .330 & $-24,63 \%$ & 705 & $-6,75 \%$ \\
\hline 2017 & 26.283 .656 & $18,89 \%$ & 38.620 .346 & $23,13 \%$ & 681 & $-3,40 \%$ \\
\hline
\end{tabular}

Source: Repuclic of Turkey Ministry of Culture and Tourism 
Turkey was determined as the $10^{\text {th }}$ most popular tourist destination in the world by $\mathrm{UNWTO}^{1}$.By the end of 2017, there were 12,856 registered accommodation facilities. 9,186 of these facilities were licensed by their respective municipalities, while the remaining 3,670 held tourism operation licenses. The combined total bed capacity of these facilities exceeds $1,482,492^{2}$. After the completion of the already continuing 281 projects, 74,130 much-needed beds will be contributed to Turkey's short supply.

Turkey has 7,200 km of coastline and ranks 2nd among 38 countries with its 454 blueflag beaches; only Spain has more blue-flag beaches than Turkey with 579. There are also 22 blue-flag marinas. The number of hotel chains and groups has doubled since 2001, hitting 165 today. The number of hotels in these 165 chains totals 824. In addition, 82 percent of chain and group hotels are domestically owned, 15 percent of these are foreign owned, while 3 percent of these have domestic and foreign partners ${ }^{2}$.

The direct contribution of tourism to the economy has been generally evaluated in terms of the percentage of the tourism revenue to GDP and percentage of employment provided by tourism sector. In order to better point out the current standing of Turkey in tourism sector, the Figure 1 presents the direct contribution of the tourism sector as percentage of GDP and employment of the OECD countries as of 2016 or latest year available. While OECD average of tourism as \% of GDP is $4.2 \%$, the average employment provided by tourism sector is $6.9 \%$. The figures of Turkey lie at the third right side columns and indicate that the figure for the first indicator is nearly at the level of the average $4.2 \%$, but the employment percentage of Turkey is higher than the average and close to $12.5 \%$. The competitors of Turkey in outbound tourism sector are mainly Greece and Spain. The indicators of both of the countries are above the OECD averages which mean the tourism sectors have higher direct contribution to the relevant economies.

${ }^{1}$ https://www.e-unwto.org/doi/pdf/10.18111/9789284419029

${ }^{2} \mathrm{http}: / / w w w . i n v e s t . g o v . t r / e n-U S /$ sectors/Pages/WellnessAndTourism.aspx 


\section{Figure 1: Direct Contribution of Tourism to Economies of OECD Countries $^{3}$}

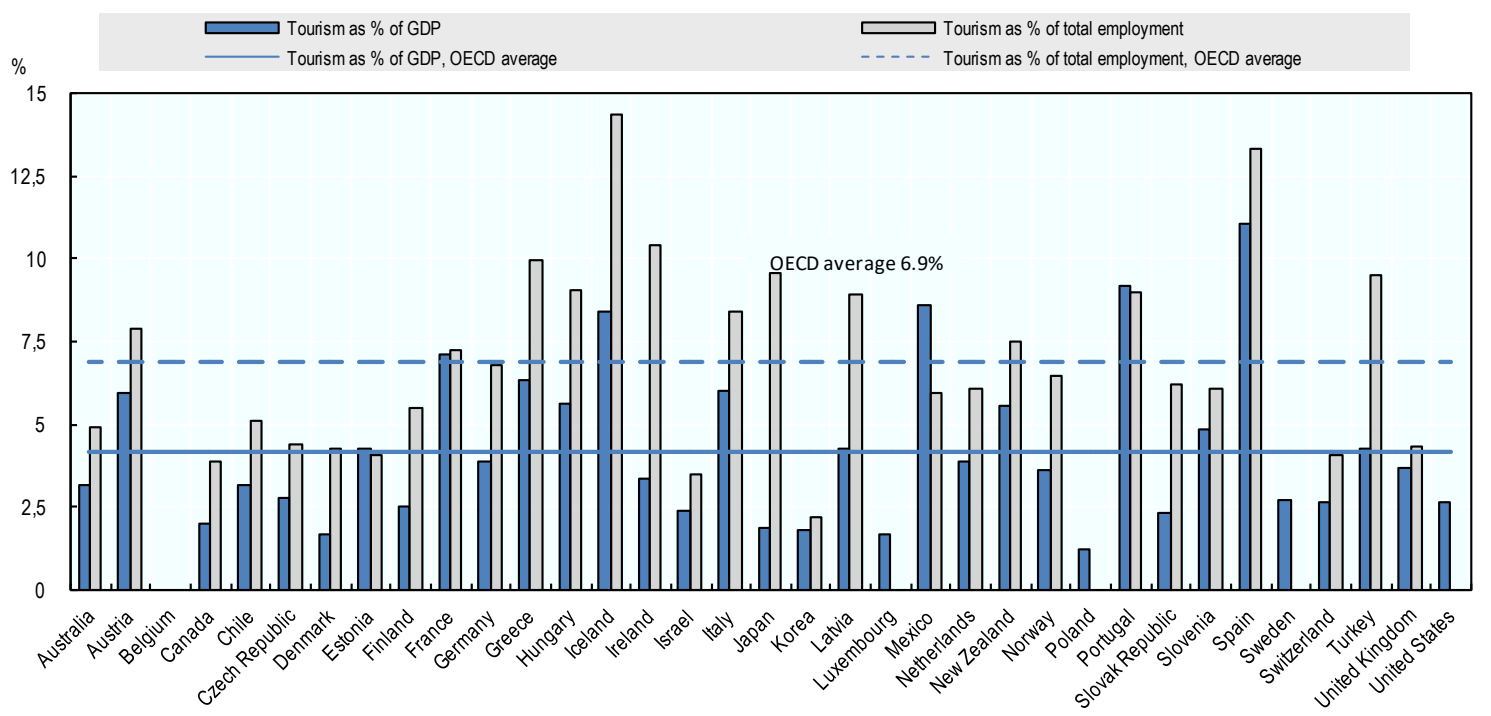

Source: OECD Tourism Statistics (Database).

Turkey, Spain and Greece are direct substitutes with each other as all have very similar attributes as outbound tourism destinations. The demand conditions cyclically favors the countries as was realized in 2015 when Spain and Greece benefited from the decline in tourism in Turkey because of the realized and possible terrorist attacks, and in 2017 when the demand to Turkish destinations of especially German tourists soured against the other two destinations.

In 2007, the tourism ministry of Turkey released an official document which incorporates an ambitious and extremely detailed plan to achieve 50 million tourist arrivals and revenues of USD 50 billion by 2023. The objective was indicated as; "Become one of the top five visited countries in the world, therefore generating mass tourism revenue." The targets and objectives have been already confirmed by the government in $2018^{4}$.

In this study, the financing sources of Turkish tourism sector are elaborated referring to the ambitious targets for 2023. It is a fact that such a public target can only be realized by new tourism investments which require the financial support of the public sector in the forms of cash and non-cash funding as well as incentives. In the first section, a

\footnotetext{
${ }^{3} 12$ http://dx.doi.org/10.1787/888933639417 (retrieved in July $21^{\text {st }}, 2018$ )

${ }^{4}$ http://www.hurriyetdailynews.com/turkish-fm-says-he-expects-50-million-tourists-by-2023-132484
} 
literature review will be performed about the financial structure of tourism sector companies. In the next section, the current financial structure of Turkish tourism sector will be evaluated and the public incentives provided to the sector will be summarized. In the third section a model will be proposed reflecting the main effects of the determined factors including the public incentives provided on the tourism receipt level. In the last section of conclusion, some recommendations will be provided.

\section{Literature}

The universal financial reporting standards require a classification of the financial sources referring to the term and the source under short and long term borrowing and shareholders' equity. The sector-related characteristics affect not only the liability side of the financial statements, but also, even more drastically, the asset side composition divided under current and non-current assets. In this framework, tourism companies can be classified as capital intensive enterprises as on average $85-90 \%$ of the assets are compromised by the fixed investments. In tourism sector, while the elasticity of demand is very high, the elasticity of the supply is considerably low. The sector is exposed to market risk, including but not limited to foreign exchange rate related risks, the interest rate risk and inflation, and also many other types of risks such as political risks (Karadeniz et al, 2015).

The literature about the financial structures of the tourism companies mainly focus on the financial preferences and the effects of those preferences on the financial performance. Dalbor and Upneja (2004) evaluated financial statements of 171 tourism companies in the period 1981-2000 and concluded that as the growth opportunities increase, so the long term borrowings. Bichon (2009) proposed that the loan applications of the tourism companies are evaluated based on the image, performance and asset structure in Europe. In their study realized by making interviews with 10 expert managers in India, Sanjeev, Gupta ve Bandyopadhyay (2012) determined that the introduction of the hotels in the financial markets, the accessibility of the trade loans and the tendency to utilize the innovative financing techniques are the main issues in the future. Fritsch and Ivy (2014) determined that the investors in the financial markets are eager to take the risk of the hotels, in exchange of higher rate of return than the other sectors. Serrasqueiro ve Nunes (2014) evaluated Small and Medium sized (SMEs) tourism companies in Portugal and reported that they firstly utilize the internal funds, then use external financing alternatives. 
The literature analyzing the financial structure of Turkish tourism companies also reports similar findings: Karadeniz (2008) reported that tourism companies initially prefer equity and for the borrowings they prefer long term. Met (2006) reported an interested finding that machinery and equipment investments of the tourism companies are generally treated as short term activities and so funded by the internal sources. The results of the study of Poyraz (2008) who analyzed 275 companies operating Mediterranean region confirmed this determination and reported that tourism companies prefer internal sources of finance, and thereafter bank loans and trade loans are used respectively. Küçükaltan ve Eskin (2008) stated that the level borrowing from the investment banks by the tourism sector is very low despite the fact that they prefer long term loans. Küçükaltan ve Açıkgöz (2011) determined a new trend of external financing for Turkish tourism companies listed in Borsa Istanbul in 2005-2009. Karadeniz et al. (2012) determined that there exist balanced financial structures of the tourism companies in terms of internal and external financings in the period 20052009. They also pointed out that for asset financing firstly internal sources and then long term borrowings are preferred. Civan ve Cenger (2013) pointed that there exist no relation with the financial structure and profitability of the tourism companies listed in Borsa Istanbul. Met et al. (2013), determined that Turkish tourism companies use the long term bank loans, short term banks loans, financial leasing and internal sources by turn to finance the renovation investments.

\section{Funding Structure of Turkish Tourism Sector}

The analysis is performed by using the aggregate financial statements as stated in Million USD for accommodation and food sector ${ }^{5}$ as for the period 2014-2016 provided by Central Bank of Turkey. The financial statements of 555 companies are aggregated. Taking the number of employees as reference as of 2016, 50.5\% of the companies are categorized under "big companies" (more than 500 employees), 44.8\% as "medium companies" (50<employees<500) and $4.7 \%$ as small (less than 50 employees). Table 2 shows the aggregate balance sheet of Turkish accommodation and food sector as 2014, 2015 and 2016 in $\mathrm{USD}^{6}$.

\footnotetext{
5 http://www3.tcmb.gov.tr/sektor/2017/menu.php

${ }^{6}$ The annual devaluation rate in USD/TL is $9 \%$ in $2014,25 \%$ in 2015 and $21 \%$ in 2016 .
} 
Table 2. Balance Sheet of Turkish Accommodation and Food Sector 2014-2016

\begin{tabular}{|c|c|c|c|c|c|c|c|}
\hline ASSETS & 2014 & 2015 & 2016 & LIABILITIES & 2014 & 2015 & 2016 \\
\hline Current Assets & 3.454 & 3.141 & 3.298 & Short term Liabilities & 3.068 & 3.011 & 3.560 \\
\hline Cash and cash equivalents & 987 & 893 & 718 & Financial Liabilities & 964 & 1.053 & 1.177 \\
\hline \multirow{2}{*}{$\begin{array}{l}\text { Marketable Securities } \\
\text { Trade receivables }\end{array}$} & 36 & 36 & 43 & Trade Payables & 950 & 833 & 1.006 \\
\hline & 817 & 834 & 866 & Other Payables & 552 & 601 & 805 \\
\hline Other receivables & 555 & 481 & 729 & Deferred Income & 430 & 361 & 375 \\
\hline Inventories & 706 & 570 & 604 & Corporate Tax Payable & 64 & 63 & 100 \\
\hline Prepaid expenses & 71 & 55 & 54 & Other Short term Liabilities & 108 & 99 & 96 \\
\hline Other current assets & 282 & 272 & 284 & Long term Liabilities & 5.645 & 5.855 & 6.817 \\
\hline Non-current Assets & 9.699 & 9.290 & $\mathbf{1 0 . 0 3 5}$ & Financial Liabilities & 5.185 & 5.416 & 6.271 \\
\hline \multirow{2}{*}{$\begin{array}{l}\text { Trade receivables } \\
\text { Other receivables }\end{array}$} & 55 & 31 & 47 & Trade Payables & 103 & 50 & 41 \\
\hline & 218 & 139 & 143 & Other Liabilities & 357 & 389 & 506 \\
\hline Investments & 1.304 & 1.323 & 1.380 & Equity & 4.440 & 3.565 & 2.956 \\
\hline \multirow{2}{*}{$\begin{array}{l}\text { Property, plant and equipment } \\
\text { Intangible assets }\end{array}$} & 6.959 & 6.760 & 7.251 & Paid in Capital & 3.690 & 3.228 & 3.365 \\
\hline & 1.008 & 900 & 968 & Retained Earnings & 591 & 694 & 958 \\
\hline \multirow[t]{3}{*}{ TOTAL ASSETS } & 13.153 & 12.431 & 13.333 & Period Net Income & 391 & -282 & -937 \\
\hline & & & & $\begin{array}{l}\text { Income Loss of Previous } \\
\text { Years }\end{array}$ & $(232,2)$ & $(73,9)$ & $(430,1)$ \\
\hline & & & & $\begin{array}{l}\text { TOTAL EQYITY AND } \\
\text { LIAB. }\end{array}$ & 13.153 & 12.431 & 13.333 \\
\hline
\end{tabular}

\begin{tabular}{|c|c|c|c|}
\hline & 2014 & 2015 & 2016 \\
\hline Current Assets & $26 \%$ & $25 \%$ & $25 \%$ \\
\hline Non-current Assets & $74 \%$ & $75 \%$ & $75 \%$ \\
\hline
\end{tabular}

Liability Composition

Source: Central Bank of Turkey

\begin{tabular}{|lccc|}
\multicolumn{1}{c}{} & $\mathbf{2 0 1 4}$ & $\mathbf{2 0 1 5}$ & $\mathbf{2 0 1 6}$ \\
\hline Short term Liabilities & $23 \%$ & $24 \%$ & $27 \%$ \\
\hline Long term Liabilities & $43 \%$ & $47 \%$ & $51 \%$ \\
\hline Equity & $34 \%$ & $29 \%$ & $22 \%$ \\
\hline
\end{tabular}

The composition of the asset side indicates the capital intensive structure of the tourism sector as $75 \%$ of total assets is compromised by the non-current assets mainly including investments, property, plant and equipment as well as intangible assets. Long and short term borrowings are the main sources of funding that represent $51 \%$ and $27 \%$ of the assets respectively. While nearly all of the long term borrowings are in the form of financial liabilities $^{8}$, more than half of short term liabilities compromised by financial liabilities (33\%) and trade payables (28\%). In conclusion the main financing source of Turkish tourism sector is long and short term loans from banks.

\footnotetext{
${ }^{7}$ http://www3.tcmb.gov.tr/sektor/2016/menu.php (retrived in July 25, 2018)

${ }^{8}$ Financial liabilities are compromised of mainly bank loans.
} 
From the perspective of bank lending, Figure 2 shows the amount of loans to tourism sector in TL and USD, as well as the share in total loans and the FX rate of USD/TL in the period 2011-2017. Turkish banking system provided 63.3 billion TL (16.8 Billion USD) cash loans to tourism sector as of the end of 2017.

Figure 2: Bank Loans to Tourism Sector 2011-2017

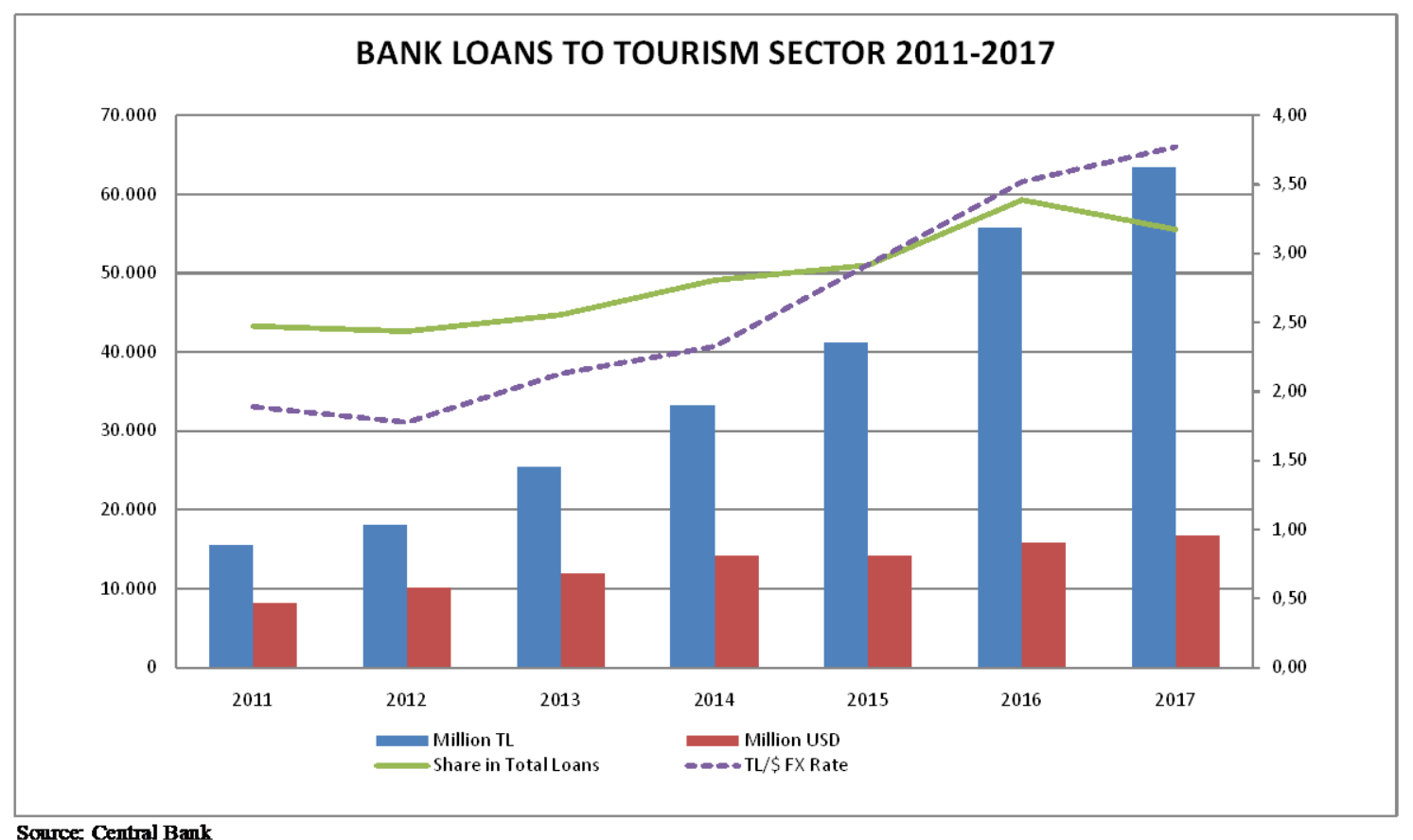

Although total loans to tourism sector in TL has increased sharply after 2015, the share in total loans has decreased to \%3.17 in 2017 after reaching the peak (3.39\%) in 2016. As a result of the devaluation in USD/TL foreign exchange rate, loan amount in USD presents more balanced developments in the period 2011-2017.

\section{The Model}

The countries that have large current account deficits typically implement strategies to increase the revenues generated from export of goods and services. In this framework, the activity level of tourism is considerably important as tourism is an investment-based sector. The investments include not only the facilities of accommodation but also modes of transportation like airports, port even roads. Generally, the foreign tourism revenues are considered as a cake and the countries with similar natural and infrastructure characteristics strive to get the possible highest share as it has been the case for Mediterranean region countries. 
Many factors affect the level of outbound tourism activity and their deterministic powers vary across countries. The following linear regression model is developed for Turkey, the variables are determined in accordance with the possible predictive power to affect tourism receipts. In order to utilize the advantage of natural log of a variable to be directly interpretable as percentage changes, to a very close approximation, the natural logarithmic values of all the variables are used for the estimation. All of the data are quarterly in the period June 2012- December 2017. Many of the data is obtained from the data base of Central Bank of Turkey, other data sources are referred in the variable explanations.

$$
\begin{aligned}
& \text { Annual Amount of Tourism Receipt } \\
& \qquad \begin{array}{l}
+\beta+\beta 1 \text { Amount of Public Incentive Disburserments } \\
+\beta 2 \text { Terrorism Index } \\
+\beta 3 \text { Real Effective Foreign Exchange Rate } \\
+\beta 4 \text { Share of Loans to Tourism Sector in Total Loans } \\
+\beta 5 \text { Average Expenditure of Tourists } \\
+\beta 6 \text { Tourism Receipt of Greece }
\end{array}
\end{aligned}
$$

It is an accepted fact that public incentives provided to the tourism sector by Turkish governments have played a vital role in the rapid increase in the number of touristic establishments and also the number of tourists coming to the country and foreign exchange income (Şanlioğlu, Ö. and Özcan, E.Ö., 2017). In this framework, the amounts of the disbursements of incentives for tourism investments are included in the model.

As already mentioned the geographical location of Turkey, as being very near to Middle East where several wars, attacks and terrorist establishments have been realized, makes it very vulnerable and target of disruptive events. Such kinds of events inevitably frighten the foreign tourists and causes considerable reduction in the number of arrivals and tourism revenues. The global terrorism index is used in the analysis ${ }^{9}$ that measures the direct and indirect impact of terrorism, including its effects on lives lost, injuries, property damage and the psychological after effects. It is a composite score that ranks countries according to the impact of terrorism from 0 (no impact) to 10 (highest impact). Turkey Terrorism Index was last updated on July of 2018.Terrorism Index in

\footnotetext{
${ }^{9} \mathrm{https}: / /$ tradingeconomics.com/turkey/terrorism-index
} 
Turkey averaged 5.68 from 2002 until 2016, reaching an all time high of 7.52 in 2016 and a record low of 4.62 in 2002.

Real effective foreign exchange rate is considered to be a proxy variable for external competitiveness by many researchers as it measures the effective prices of goods and services in competing tourism destination countries.

As it is explained in the previous section of this study, main source of funding of Turkish tourism companies is long and short term borrowings from the financial system which includes deposit banks, investment banks as well as participation banks operating under Islamic rules. It is expected that the more funding has been provided to the tourism sector, the more investment has been realized which generates more tourism income.

The average expenditure made my each tourist represent the contribution to tourism revenue and each country design the tourism system as to increase this amount. Together with the number of tourist arrivals, the average expenditure of the tourist determines the level of tourism revenue. It is expected that the higher the average expenditure per tourist, the higher the tourism revenue.

The last variable represents tourism income of major competitor country of Greece. Both of the countries have similar natural wealth as a tourism destination, also the need for tourism income as a tool to close the current account deficit is high in both countries. A negative relationship is expected between the tourism incomes of Turkey and Greece as they target the same niche consisting of Europeans especially Germans and Russians.

Table 3 reports the Stata results of linear regression for the equation specified above in which natural $\log$ of tourism revenue in USD is the dependent variable and incent represents natural $\log$ of quarterly tourism incentive disbursements, realeffxrate represents natural log of the real effective foreign exchange rate, averageexp represents natural $\log$ of the average expenditure of tourists in USD, greecetorev represents the natural $\log$ of quarterly tourism revenue of Greece, loanstoto represents the natural log of the change in the amount of loans provided to tourism sector. Terrindex represents the quarterly terrorism index. 
Referring to the R2 (adjusted R2), it can be reported that the model explains $84.53 \%$ (78.72\%) of the tourism revenue outcome. The F statistics (14.57) also indicates the model is statistically significant. In relation with the reliability of the results of the model, Breusch-Pagan/Cook-Weisberg test is performed and the result is reported at the lower part of Table 3. As the chi-square value is small, it can be concluded that heteroskedasticity is not a problem

Table 3: Model OLS Results

\begin{tabular}{|c|c|c|c|c|c|}
\hline & & & & $\begin{array}{l}\text { Number of } \\
\text { obs. } \\
\text { F(6,16) }\end{array}$ & $\begin{array}{l}=23 \\
=14,57\end{array}$ \\
\hline Source & SS & df & MS & $F(6,16)$ & \\
\hline Model & 3,04459 & 6 & 0,5074 & Prob $>F$ & $=0,0000$ \\
\hline Residual & 0,55733 & 16 & 0,03483 & R-squared & $=0,8453$ \\
\hline TotaL & 3,60192 & 22 & 0,16372 & $\begin{array}{l}\text { Adj R- } \\
\text { squared } \\
\text { Root MSE }\end{array}$ & $\begin{array}{l}=0,7872 \\
=018664\end{array}$ \\
\hline
\end{tabular}

\begin{tabular}{lrrrr} 
TOUREV & Coef. & Std.Error & $\mathbf{t}$ & P>t \\
\hline Incent & $-0,0082$ & 0,1491 & $-0,55$ & 0,589 \\
realeffxrate & 0,1651 & 0,9436 & 0,17 & 0,863 \\
averageexp & 0,3924 & 0,5557 & 0,71 & 0,49 \\
greecetorev & 0,3379 & 0,0401 & 8,42 & 0 \\
loanstoto & 0,0029 & 0,0117 & 0,25 & 0,806 \\
Terrindex & $-0,1342$ & 0,0856 & $-1,57$ & 0,136 \\
Const & 10,68 & 4,565 & 2,34 & 0,033 \\
\hline
\end{tabular}

Despite the high overall statistically significance level of the model, only the coefficient of the independent variable of greecetorev (which represents the tourism revenue of Greece) is statistically significant. Against the expectations, it has a positive relation with the tourism revenue of Turkey. Another interesting finding is the negative coefficient of incent (the quarterly incentive payments) although it is not statistically significant. This can be interpreted as the existing incentive structure is not adequate to positively affect tourism revenue. The positive sign of the coefficient of realeffxrate (the real effective foreign exchange rate) shows the increase in the purchasing power of the foreign tourists resulting from the devaluation of TL which generates higher tourism 
revenue for Turkey; however the coefficient is not statistically significant ${ }^{10}$. In line with the expectations, the coefficient of averagexp (average expenditure) is the highest positive value, amongst all the other variables, however it is not also statistically significant. As there is a contradicting result for the incentive disbursements, the coefficient of the other variable related with the financial structure loanstoto (change in the amount of loans) is negligible. The negative effect of the terrorism on the tourism revenue is confirmed by the results as the coefficient of terrindex is negative but it is also not statistically significant.

\section{The Conclusion}

Tourism is amongst the largest economic sectors of the world. It is estimated that Travel $\&$ Tourism sector is shown to account for $10.4 \%$ of global GDP and 313 million jobs, or $9.9 \%$ of total employment, in 2017. In fact the growth in the tourism sector outpaced the global economy for seven successive years and reached its peak with $4.6 \%$ growth directly. In 2017 the detrimental effects of the terrorism on tourism particularly in Tunisia, Turkey and Egypt has been eased and the positive trend seems to continue in 2018.

According to Travel \& Tourism Economic Impact 2018 Report of World Travel \& Tourism Council (WTTC), for Turkey the direct contribution of travel \& tourism which reflects the economic activity generated by industries such as hotels, travel agents, airlines and other passenger transportation to GDP in 2017 was TRY 116.7bn (USD32.0bn), 3.8\% of GDP. The total contribution which includes wider effects from investment, the supply chain and induced income impacts, is higher with a level of TRY359.1bn (USD98.4bn), 11.6\% of GDP in 201711. More than 70 percent of tourism revenue of Turkey is generated from 20 countries which are Germany, Russia, England, Iran, Netherland, France, USA, Bulgaria, Belgium, Italy, Austria, Georgia, Sweden, Ukraine, Azerbaijan, Syria, Greece, Switzerland, Denmark and Spain, ranked by the amounts 9 .

\footnotetext{
${ }^{10}$ This finding confirms the find of Dincer et al. (2015) that empirically tests tourism expenditures, tourism revenues and number of foreign tourists in Turkey by reliance on the REER. According to the results of the study, no long term relationship is detected between REER and tourism revenues and no granger causality relationship is found. ${ }^{11}$ https://www.wttc.org/-/media/files/reports/economic-impact-research/countries-2018/turkey2018.pdf
} 
In the same year Turkey recorded a Current Account deficit (CAD) of 5.50\% GDP. The long lasting macroeconomic problem of Turkey has been CAD which has averaged $2.52 \%$ of GDP from 1980 until 2017. All of the governments have strived to close this deficit through time by several strategies. They have offered several incentives such as reduced utility prices, funding alternatives for tourism investments and reduced tax rates, while pursuing policies aimed at eliminating any bureaucratic barriers that may hinder growth in the tourism sector. In 2007, the tourism ministry of Turkey released an official document which incorporates an ambitious and extremely detailed plan to achieve 50 million tourist arrivals and revenues of USD 50 billion by 2023 .

In this framework, the aim of this study is twofold; firstly the debut analysis of the funding structure of Turkish tourism sector is realized by using the aggregate balance sheet of 555 tourism companies as provided by Central Bank of Turkey. The data represents the general structure of the tourism sector as of the end of 2017 as capital intensive $(75 \%$ of total assets is compromised by the non-current assets mainly including investments, property, plant and equipment as well as intangible assets) and the major source of funding is borrowing ( $78 \%$ of total assets, mainly from the financial institutions. From the perspective of bank lending, it is determined that total loans to tourism sector in TL has increased sharply after 2015, whereas the share in total loans has decreased to \%3.17 in 2017 after reaching the peak (3.39\%) in 2016.

Thereafter a model is proposed by using the linear regression by which the effects of the variables of public incentive disbursements, terrorism index, Real Effective Foreign Exchange Rate, Share of Loans to Tourism Sector in Total Loans provided by financial system, average expenditure incurred by tourist and the tourism receipt level of major and geographically more substitute competitor of Greece on Tourism revenue level is examined. The natural logarithmic values of all variables are used and it is determined that model explains $84.53 \%$ of the tourism revenue outcome and the model is statistically significant. However, individual variables except tourism revenue of Greece are determined as not statistically significant.

\section{REFERENCES}

Bichon, P (2009) Europe: Refinancing a Hotel in Today's Restricted Debt Markets. http://www.hvs.com/article/4307/europe-refinancing-a-hotel-in-todays-restricted-debt/ (Accessed at: 28.07.2018) 
Civan M and Cenger H (2013) Borsada İşlem Gören Turizm İşletmelerinin Finansal Yapı ve Karlılık Oranları Arasındaki İlişkinin Analizi. 17.Finans Sempozyumu. Muğla: Muğla Üniversitesi, 354-363

Dalbor MC and ve Upneja A (2004) The Investment Opportunity Set and the Long-Term Debt Decision of U.S. Lodging Firms. Journal of Hospitality \& Tourism Research 28(3): 346-355.

Dincer MZ, Dincera F and Ustaoglu M (2015) Reel Effective Exchange Rate Volatilities Impact On Tourism Sector In Turkey: An Empirical Analysis of 2003-2014. Procedia Economics and Finance 23: 1000 - 1008.

Karadeniz E (2008). Türk Konaklama İşletmelerinde Sermaye Yapısını Etkileyen Faktörlerin Analizi. PhD Thesis, Çukurova Üniversitesi, Sosyal Bilimler Enstitüsü, Turkey.

Karadeniz E, İskenderoğlu O and Önal YB (2015) Testing of Gibrat Propotional Law on Borsa Istanbul Tourism Companies. Niğde Üniversitesi İktisadi ve İdari Bilimler Fakültesi Dergisi 8 (1): 131-139.

Karadeniz E, İskenderoğlu Ö, Kandır SY and Onal YB (2012) Türkiye Cumhuriyet Merkez Bankası Sektör Bİlançoları Yardımıyla Oteller ve Lokantalar Sektörünün Finansman Kararlarının İncelenmesi. Seyehat ve Otel İşletmeciliği Dergisi 8: 17-28.

Küçükaltan KD and Açıkgöz AF (2011) Uluslararası Otel İşletmelerinin Finansmanı. Journal of Travel and Hospitality Management 14 (2): 157-170.

Küçükaltan K and Eskin İ (2008). Türkiye'deki Otel İşletmelerine Bir Finansman Modeli Olarak Teşvikler. Trakya Üniversitesi Sosyal Bilimler Dergisi 10(2): 158-172.

Met Ö (2006) Taksitli Krediler ile Finansman ve Otel-Restoran Ekipmanı Satıcılarına Yönelik Bir Araştırma. Marmara Üniversitesi Muhasebe-Finansman Araştırma ve Uygulama Dergisi 7(16): 35-46.

Met Ö, Özdemir İM and Erdem B (2013) Otel Sektöründe Yenileme Yatırımlarının Finansmanı: Marmariste Bir Araştırma. Sosyo Ekonomi 9(19): 263-276.

Poyraz E (2008) Büyük Ölçekli Otel İşletmelerinin Orta ve Uzun Vadeli Fon Temini Sorunu Ve Sermaye Piyasalarına Açılma Eğiliminin Analizi için Yönetici Tutumlarının Araştırılması. Muhasebe ve Finansman Dergisi 37: 142-157.

Sanjeev GM, Gupta K and Bandyopadhyay R (2012) Financial challenges in the Indian hospitality industry. Worldwide Hospitality and Tourism Themes 4(2): 163-173.

Serrasqueiro Z and Nunes PM (2014) Financing Behaviour of Portuguese SMEs in Hotel İndustry. International Journel of Hospitality Management 43: 98-107.

Şanlioğlu Ö and Özcan EÖ (2017) Türkiye'de Uygulanan Turizm Teşvik Politikalari Ve Sonuçlari Üzerine Bir Değerlendirme. Kırıkkale Üniversitesi Sosyal Bilimler Dergisi Cilt 7(2).

UNWTO Tourism Highlights (2017) Available at: www.eunwto.org/doi/pdf/10.18111/9789284419029 (accessed 17 July 2018).

Tourism(2018) Available at: http://www.invest.gov.tr/enUS/sectors/Pages/Wellness AndTourism.aspx(accessed 20 July 2018). 
Turkish FM says he expects 50 million tourists by 2023, Hürriyet, May 28, 2018. Available at: http://www.hurriyetdailynews.com/turkish-fm-says-he-expects-50-million-tourists-by-2023132484(accessed 25 July 2018).

Sektör

Bilançoları

(2014-2016)

Available

at:

http://www3.tcmb.gov.tr/sektor/2017/menu.php(accessed 25 July 2018).

Turkey Terrorism Index Available at: https://tradingeconomics.com/turkey/terrorism-index (accessed 27 July 2018).

Travel \& Tourısm Economic Impact 2018 Turkey. Available at: https://www.wttc.org//media/files/reports/economic-impact-research/countries-2018/turkey2018.pdf (accessed 30 July 2018). 